\section{Treatment of systemic lupus erythematosus: don't forget hydroxychloroquine}

We read with interest the last 2019 update of the European League Against Rheumatism recommendations for the management of systemic lupus erythematosus (SLE). ${ }^{1}$ We agree with the comment by Gabriel Figueroa-Parra et al concerning the lack of mention of chloroquine as major treatment in SLE. ${ }^{2}$

Concerning survival, the LUMINA study group also showed that use of hydroxychloroquine (HCQ) was associated with a greater survival rate in 608 patients with SLE. ${ }^{3}$ Ruiz-Irastorza et al confirmed these results in 232 patients with SLE. ${ }^{4}$ The 15 -year survival rate was 0.95 for patients using HCQ versus 0.68 for patients without antimalarial therapy. Finally, use of HCQ was also independently associated with a greater survival in a population of patients with SLE with nephritis. ${ }^{5}$

The LUpus in MInorities, NAture versus nurture (LUMINA) study group also showed that patients without HCQ had higher damage scores and were more likely to have renal disease or central nervous system disease and use of HCQ was associated with a reduced risk of developing new damage in multivariate analysis. ${ }^{3}$ The Canadian Hydroxychloroquine Study Group realised a double-blinded, placebo-controlled study that included patients with SLE to compare HCQ with placebo. ${ }^{6}$ The risk of SLE flares (including major flares) increased by 2.5 at the end of the 6-months follow-up period in the placebo group compared with the HCQ group. During the additional 3 years follow-up study, use of HCQ reduced major flares by $57 \% .^{7}$ Meinao et al published another double-blind placebo-controlled trial with chloroquine diphosphate steroid requirements and SLE Disease Activity Index score were higher in the placebo group and the flare risk was 4.6 times greater in the placebo group. ${ }^{8}$

Moreover, patients with lower blood HCQ concentrations have greater SLE disease activity and have a greater risk of disease flare. ${ }^{9} 10$

During pregnancy, HCQ use is essential. It reduces risks of pre-eclampsia, cutaneous neonatal lupus erythematosus, fetal growth restriction and prematurity. ${ }^{11-13}$

In conclusion, HCQ is still in 2019, the cornerstone of the treatment of SLE.

\section{Martin Michaud, ${ }^{\ominus}$ Florian Catros, Sophie Ancellin, Francis Gaches} Department of Internal Medicine, Hopital Joseph Ducuing, Toulouse, France

Correspondence to Dr Martin Michaud, Department of Internal Medicine, Joseph Ducuing Hospital, 31076 Toulouse, France; mmichaud@hjd.asso.fr
Contributors All authors contributed to write the manuscript.

Funding The authors have not declared a specific grant for this research from any funding agency in the public, commercial or not-for-profit sectors.

Competing interests None declared.

Patient consent for publication Not required.

Provenance and peer review Not commissioned; internally peer reviewed.

(c) Author(s) (or their employer(s)) 2019. No commercial re-use. See rights and permissions. Published by BMJ.

\section{Check for updates}

To cite Michaud M, Catros F, Ancellin S, et al. Ann Rheum Dis Epub ahead of print: [please include Day Month Year]. doi:10.1136/annrheumdis-2019-215799

Received 29 May 2019

Accepted 30 May 2019

Ann Rheum Dis 2019:0:1. doi:10.1136/annrheumdis-2019-215799

\section{REFERENCES}

1 Fanouriakis A, Kostopoulou M, Alunno A, et al. Update of the EULAR recommendations for the management of systemic lupus erythematosus. Ann Rheum Dis 2019:2019:736-45.

2 Gabriel Figueroa-Parra G, Gamboa-Alonso CM, De-Leon-Ibarra AL, et al. update of the EULAR recommendations for the management of SLE: don't forget chloroquine. Ann Rheum Dis 2019;2019.

3 Alarcón GS, McGwin G, Bertoli AM, et al. Effect of hydroxychloroquine on the survival of patients with systemic lupus erythematosus: data from LUMINA, a multiethnic US cohort (LUMINA L). Ann Rheum Dis 2007;66:1168-72.

4 Ruiz-Irastorza G, Egurbide M-V, Pijoan J-I, et al. Effect of antimalarials on thrombosis and survival in patients with systemic lupus erythematosus. Lupus 2006;15:577-83.

5 Zheng ZH, Zhang LJ, Liu WX, et al. Predictors of survival in Chinese patients with lupus nephritis. Lupus 2012;21:1049-56.

6 The Canadian Hydroxychloroquine Study Group. A randomized study of the effect of withdrawing hydroxychloroquine sulfate in systemic lupus erythematosus. N Engl J Med 1991:324:150-4.

7 Tsakonas E, Joseph L, Esdaile JM, et al. A long-term study of hydroxychloroquine withdrawal on exacerbations in systemic lupus erythemato- Sus. Lupus 1998;7:80-5.

8 Meinão IM, Sato El, Andrade L, et al. Controlled trial with chloroquine diphosphate in systemic lupus erythematosus. Lupus 1996;5:237-41.

9 Costedoat-Chalumeau N, Amoura Z, Hulot J-S, et al. Low blood concentration of hydroxychloroquine is a marker for and predictor of disease exacerbations in patients with systemic lupus erythematosus. Arthritis Rheum 2006:54:3284-90.

10 Costedoat-Chalumeau N, Galicier L, Aumaître 0, et al. Hydroxychloroquine in systemic lupus erythematosus: results of a French multicentre controlled trial (plus study). Ann Rheum Dis 2013;72:1786-92.

11 Seo MR, Chae J, Kim YM, et al. Hydroxychloroquine treatment during pregnancy in lupus patients is associated with lower risk of preeclampsia. Lupus 2019;28:722-30.

12 Barsalou J, Costedoat-Chalumeau N, Berhanu A, et al. Effect of in utero hydroxychloroquine exposure on the development of cutaneous neonatal lupus erythematosus. Ann Rheum Dis 2018;77:1742-9.

13 Guillotin V, Bouhet A, Barnetche T, et al. Hydroxychloroquine for the prevention of fetal growth restriction and prematurity in lupus pregnancy: a systematic review and metaanalysis. Joint Bone Spine 2018:85:663-8. 